\title{
Nesting Behavior of Introduced Brown Basilisks (Basiliscus vittatus) in Southern Florida
}

\author{
James T. Stroud ${ }^{1,2}$ and Sean T. Giery ${ }^{3}$ \\ ${ }^{1}$ Department of Biological Science, Florida International University, 11200 SW $8^{\text {th }}$ St., Miami, Florida 33199 (jameststroud@gmail.com) \\ ${ }^{2}$ Fairchild Tropical Botanical Gardens, Coral Gables, Florida 33156 \\ ${ }_{3}^{3}$ Department of Biological Science, North Carolina State University, Raleigh, North Carolina 27695-7617 (stgiery@gmail.com)
}

Photographs by the senior author.

$\mathrm{F}$ lorida is a hotspot for non-native reptiles and amphibians, which account for about $39 \%$ of all herpetofaunal species reported in the state (56 of 198 species [Krysko et al. 2011], with 47 of them classified as reproductively established [Meshaka et al. 2011]). Florida's subtropical climate and port access provide opportunities for the establishment of non-native herpetofauna, usually as a consequence of release or escape following importation for the pet trade or as incidental stowaways in the plant-nursery trade (Engeman et al. 2011). Although extensive efforts have been made to document the presence and distribution of all alien herpetofauna in Florida (i.e., Krysko et al. 2011), major gaps in knowledge about the natural history of many species remain. Particularly important are details concerning reproductive behavior and ecology, which may ultimately determine the success and impact of many introduced species. Herein we document the nesting behavior (nest site selection and oviposition) of a wild female Brown Basilisk (Basiliscus vittatus) at Fairchild Tropical Botanical Gardens, Coral Gables Florida, and the incubation and hatching details of the entire clutch.

Fairchild Tropical Botanical Gardens is a ca. 40-hectare landscaped garden hosting ca. 4,100 pantropical plant species. Unintentionally, the garden also supports a diverse nonnative lizard community that includes Cuban Brown Anoles (Anolis sagrei), Puerto Rican Crested Anoles (A. cristatellus), Hispaniolan Bark Anoles (A. distichus), Cuban Knight Anoles (A. equestris), Brown Basilisks (Basiliscus vittatus), Green Iguanas (Iguana iguana), Peters's Rock Agamas (Agama picticauda), Common House Geckos (Hemidactylus frenatus), Mediterranean House Geckos (H. turcicus), Indo-Pacific House Geckos (H. garnotti), and Tropical House Geckos (H. mabouia; Stroud 2014). Northern Curly-tailed Lizards (Leiocephalus carinatus) and Tokay Geckos (Gekko gecko) also are present but extremely rare and seldom seen (the presence of the latter first confirmed by their unique vocalizations audible during nocturnal surveys). Additionally, the following native lizard species have been observed: Green Anoles ( $A$. carolinensis), which are phenotypically indistinguishable from Cuban Green Anoles (A. porcatus; Camposano 2011) that also have been recorded in the region using molecular methods (Kolbe et al. 2007), Reef Geckos (Sphaerodactylus notatus), and Southeastern Five-lined Skinks (Plestiodon inexpectatus).

\section{Brown Basilisk ecology and distribution in southern Florida}

Basiliscus vittatus (Corytophanidae; Figs. 1 and 2) are native to Central and South America (Central Mexico to Colombia; Powell et al. 2016), where they inhabit tropical and subtropical forests across a wide gradient of disturbance (Krysko et al. 2006). Outside of their native range, Brown Basilisks are widely distributed throughout southern Florida after an initial introduction to Miami-Dade County in 1976 (Wilson and Porras 1983), although an animal importer reported purposefully releasing Basliscus vittatus - incorrectly labeled as B. basiliscus at the time (Greene et al. 2012) — in 1964 (King and Krakauer 1966). Basiliscus vittatus is a popular and affordable species in the pet trade, and like most other established non-native lizards in southern Florida, that is the likely venue through which initial colonizers were established (either via escapes or intentional release). Currently, in addition to Miami-Dade County, B. vittatus populations can be found in Broward, Collier, Palm Beach, St. Lucie (Krysko et al. 2006), Glades (Crutchfield and Enge 2008), and Indian River (Rand et al. 2008) counties (Krysko et al. 2011; Meshaka, 2011). However, both natural range expansion and new satellite population establishment still is occurring; the first established population in the Florida Keys was recently described from Key Largo, Monroe County (Greene et al. 2012). 


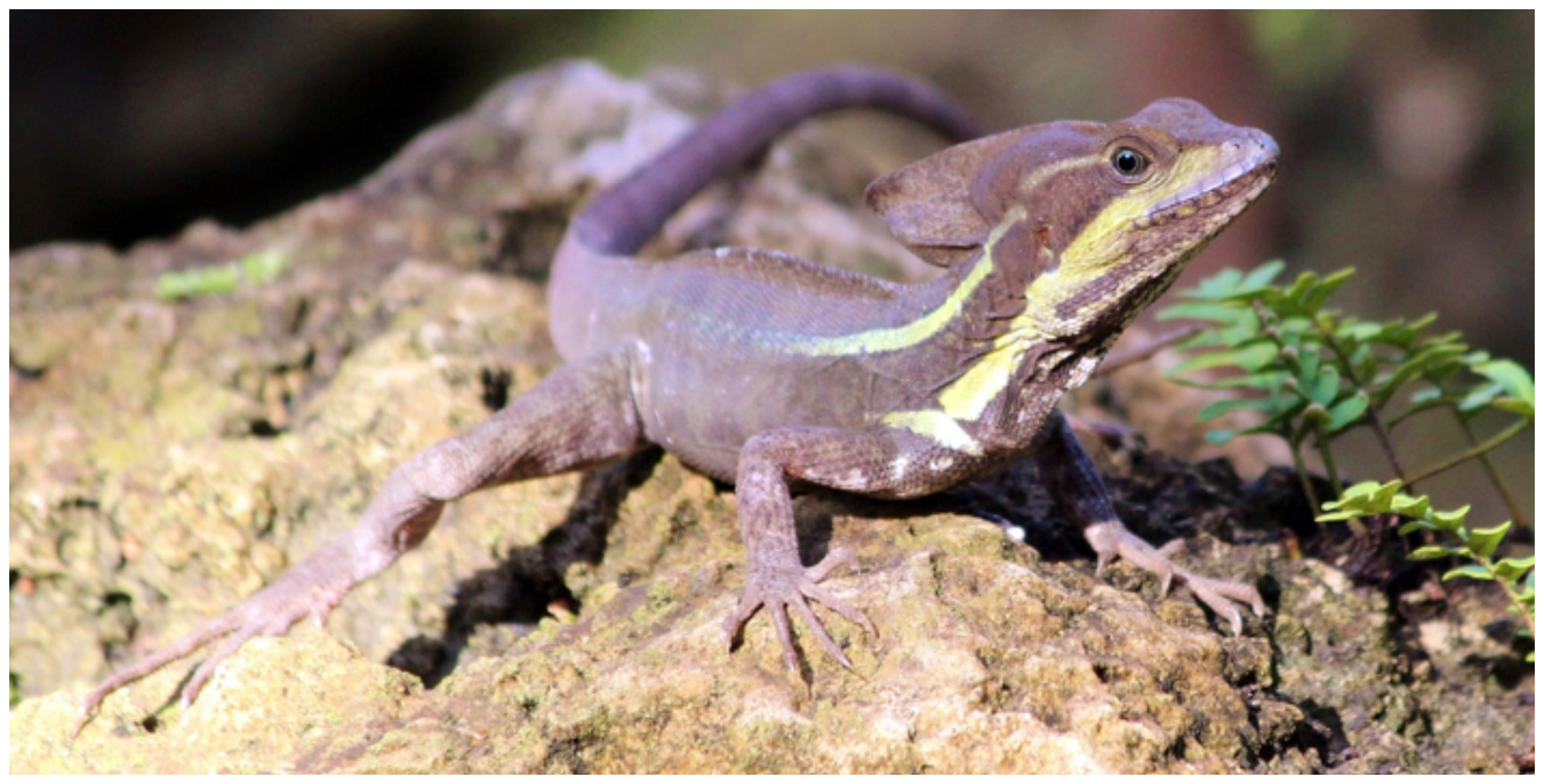

Fig 1. Adult male Brown Basilisk (Basiliscus vittatus) on rocks at Fairchild Tropical Botanical Gardens, Coral Gables Florida. Note the enlarged triangular head crest that differentiates mature males from females (see Fig. 2).

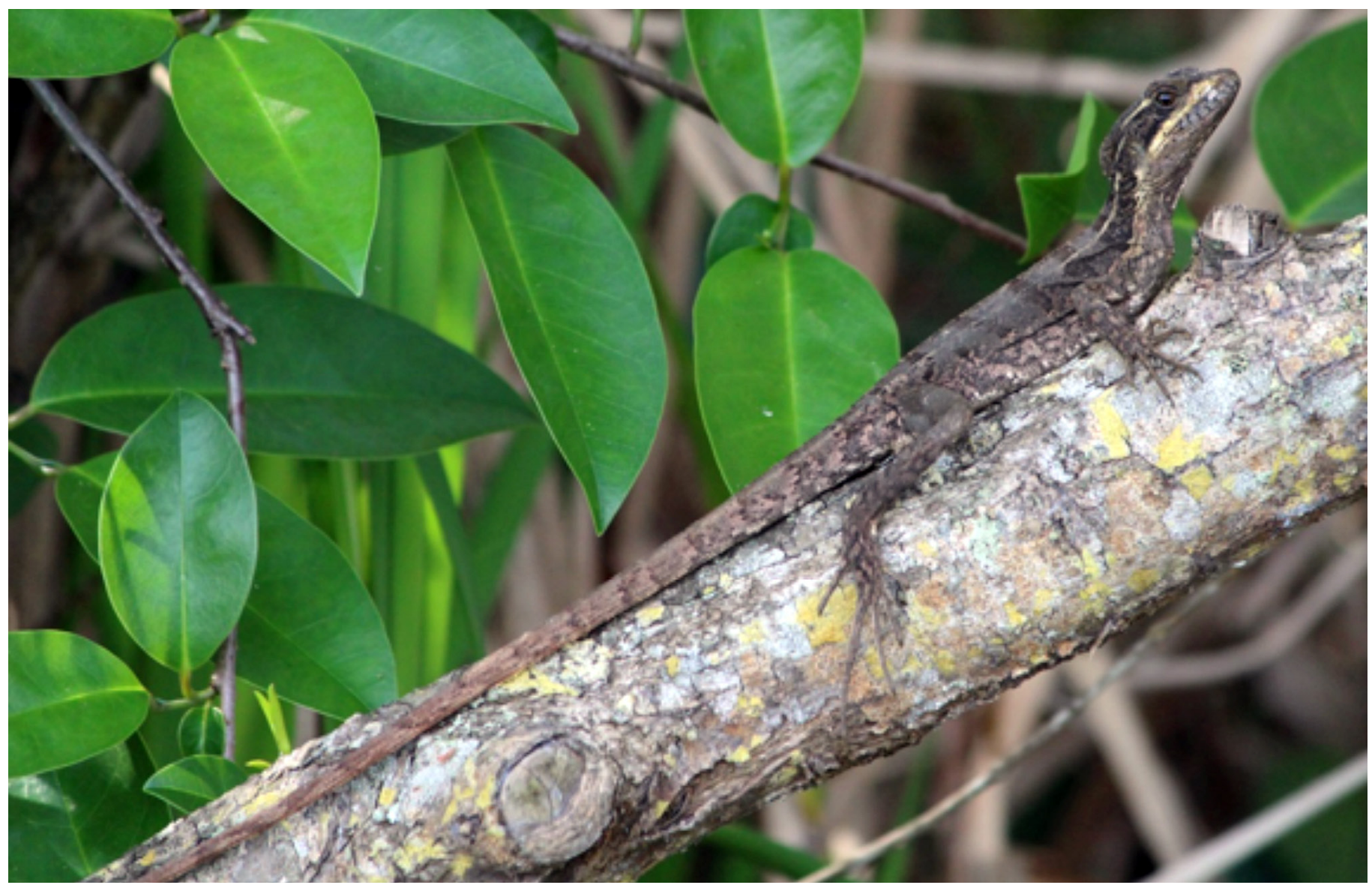

Fig 2. Adult female Brown Basilisk (Basiliscus vittatus) on the branch of a Buttonwood Tree (Conocarpus erectus), at Fairchild Tropical Botanical Gardens, Coral Gables Florida. Females have a hood-like lobe on the neck behind the head. 
Basiliscus vittatus is the only corytophanid presently established in Florida; although occasional individual Plumed Basilisks (B. plumifrons) have been collected, that species apparently has failed to establish any reproductively active populations (Bartlett and Bartlett 1999; Krysko et al. 2006; Meshaka 2011). Brown Basilisks are medium-sized lizards (SVL ca. $115 \mathrm{~mm}$ females, $134 \mathrm{~mm}$ males; Savage 2002) that are predominantly insectivorous (Krysko et al. 2006), but also opportunistically consume fruit (Ficus sp.; Meshaka et al. 2004) and vertebrate prey (e.g., smaller Anolis lizards; J Stroud, pers. obs.). These lizards are semi-arboreal aquatic specialists, and so are very rarely found far from vegetation surrounding water. During anti-predator evasion, $B$. vittatus often engages in bipedal locomotion to increase sprint speed. In smaller individuals, extended scales on the toes provide enough surface tension for lizards to run across water for short distances without breaking surface tension (Snyder 1949); this accounts for the vernacular name, "Jesus Lizard" (e.g., Powell et al. 2016).

\section{Reproductive ecology and nesting behavior}

Brown Basilisks typically reach reproductive maturity at 6 mo (Savage 2002). Gravid females are present in Miami from late February and early March through October, with nest-site excavations beginning during early-mid-March. In Florida, females could lay at least two clutches of four to six eggs per year, one in early spring and another in the fall (Meshaka et al. 2004). In their native range, females have been recorded depositing as many as four clutches annually, with clutch sizes of 2-6 eggs (Krysko et al. 2006).

At 1753 h on 18 March 2016, we observed an adult female Brown Basilisk (ca. $100 \mathrm{~mm}$ SVL) lying on the ground in an open grassy area within $-5 \mathrm{~m}$ of a brackish pond (Fig. 3) at Fairchild Tropical Botanical Gardens $\left(25.676^{\circ} \mathrm{N}\right.$, $80.274^{\circ} \mathrm{W} ;<1 \mathrm{~m}$ elev.). Once approached, the lizard retreated to a Buttonwood Tree (Conocarpus erectus) bordering the pond. The habitat in the area is dominated by Buttonwood Trees, Red Mangroves (Rhizophora mangle), Black Mangroves

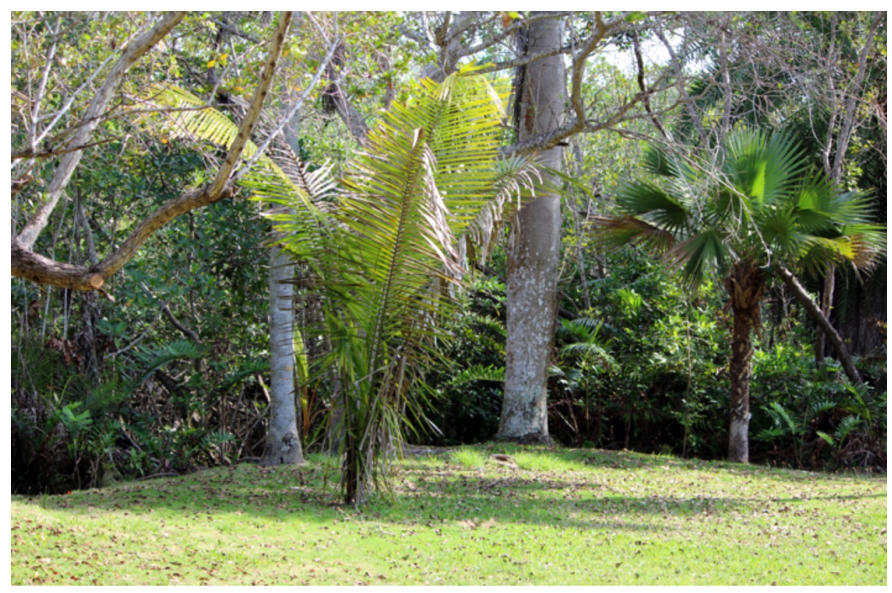

Fig 3. Vegetation surrounding nest site (see Fig. 4), at Fairchild Tropical Botanical Gardens, Coral Gables, Florida.
(Avicennia germinans), Coconut Palms (Cocos nucifera), Brazilian Canopy Palms (Attalea oleifera), Mauritian Blue Latan Palms (Latania loddigesii), Réunion Red Latan Palms (L. lontaroides), Bermuda Palmettos (Sabal bermudana), and Jamaican Mountain Cabbage Palms (Roystonea altissima). On closer inspection, the lizard was in the process of depositing eggs (Fig. 4). We retreated and watched the female return to the egg-laying site within $\sim 15$ minutes. After ovipositing, the female re-applied excavated substrate (Fig. 5). We sub-

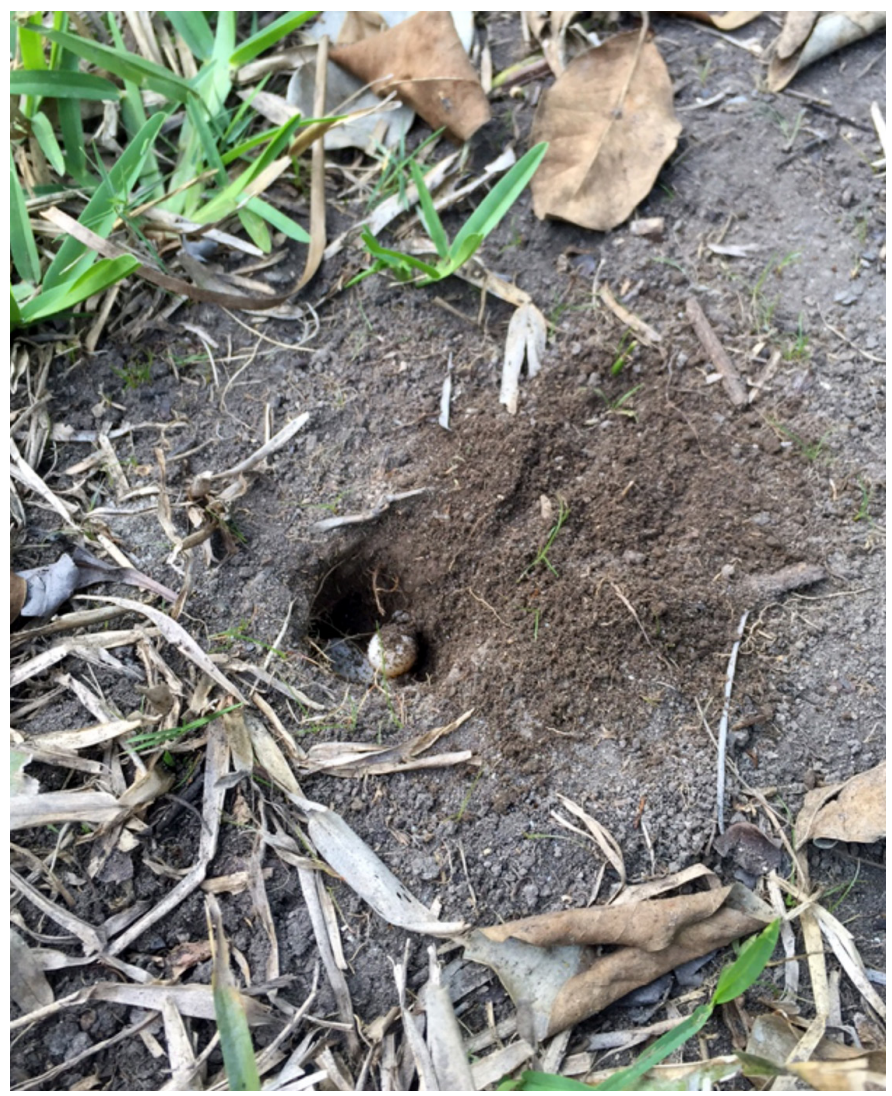

Fig 4. Nest-site selection and oviposition of a Brown Basilisk (Basiliscus vittatus) clutch. The female was momentarily displaced by our presence, but returned to complete the re-application of soil (see Fig. 5).

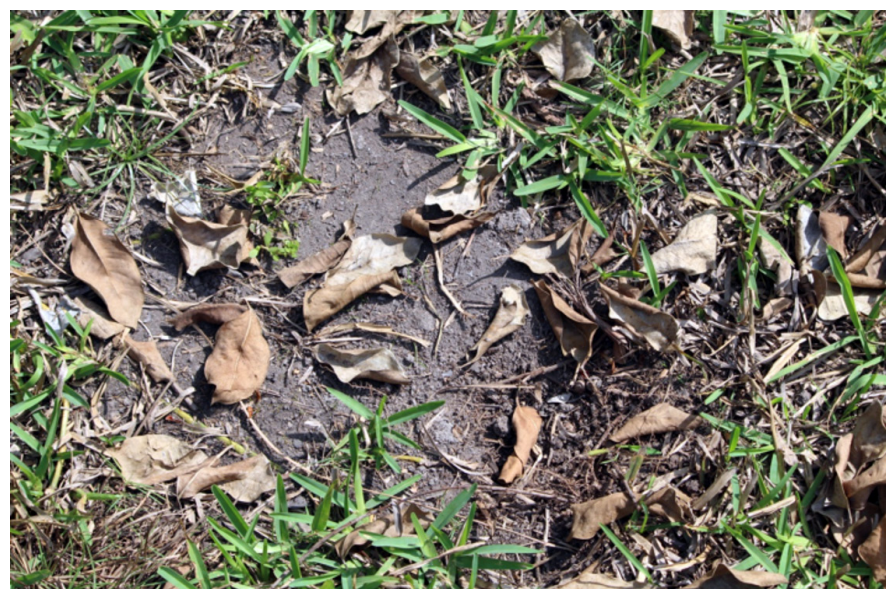

Fig 5. Once oviposition was complete, the female returned excavated substrate to cover the eggs, and even brushed leaves across the nesting site. 
sequently excavated the entire clutch into a small container filled with the same substrate in which it had been laid.

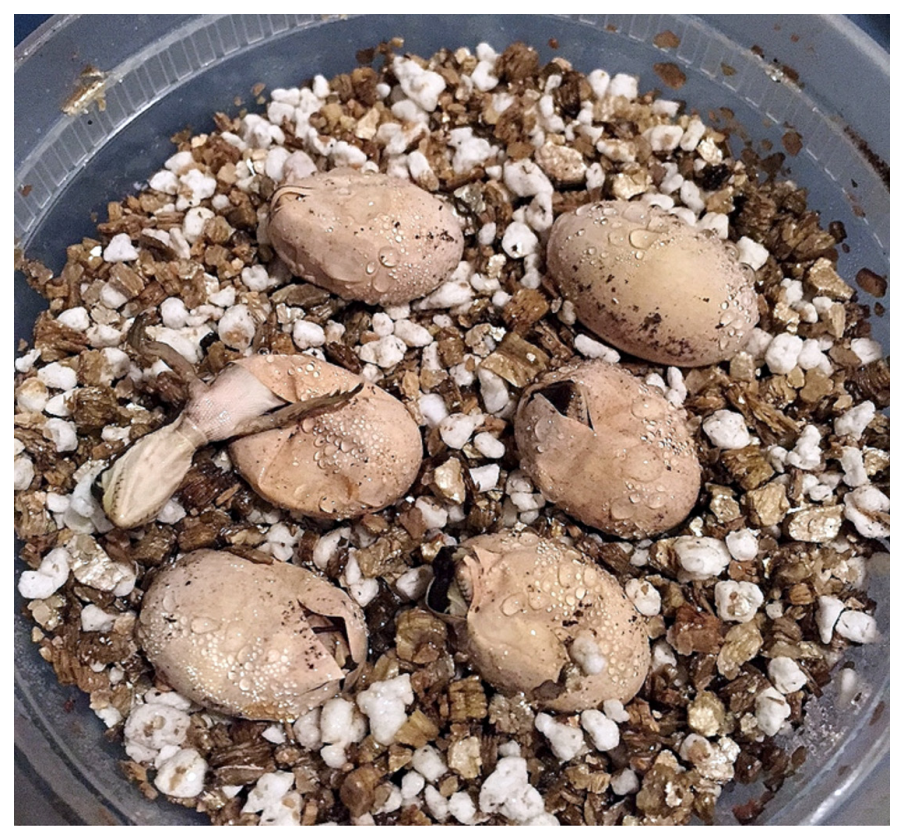

Fig 6. Brown Basilisks (Basiliscus vittatus) first emerging from eggs 66 days after deposition. All individuals hatched within $24 \mathrm{~h}$.

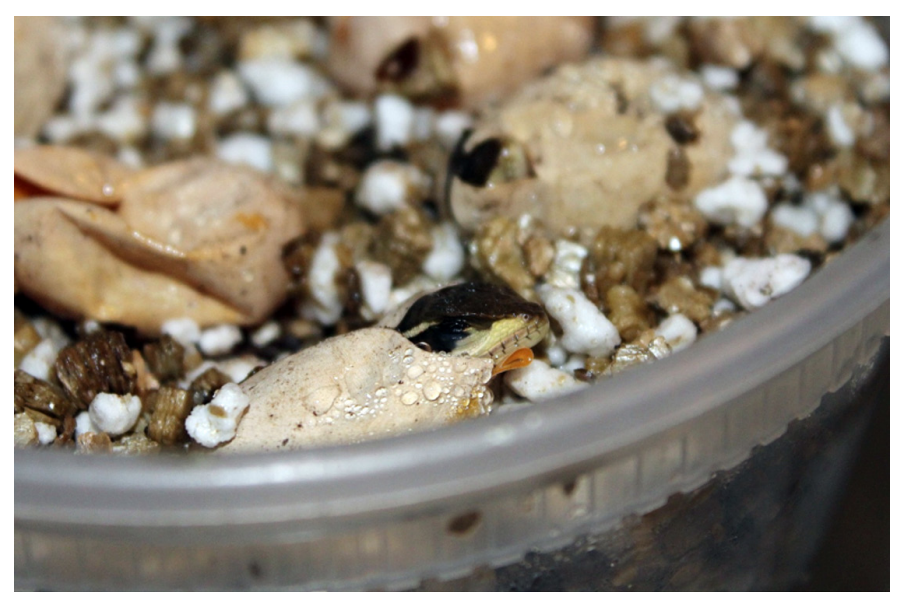

Fig 7. Hatching Brown Basilisk (Basiliscus vittatus).

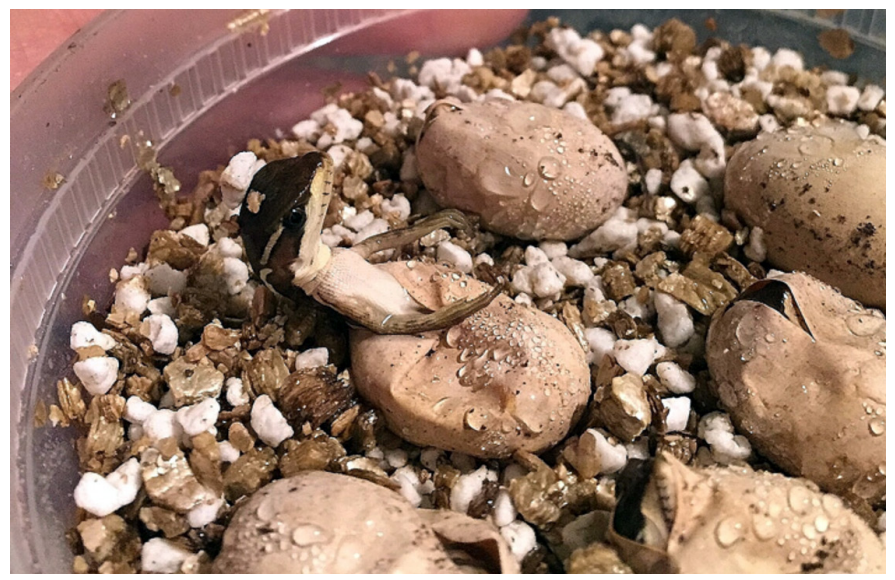

Fig 8. Hatching Brown Basilisk (Basiliscus vittatus).

\section{Egg incubation and hatching}

The clutch consisted of six eggs that were incubated at ambient shaded temperatures that fluctuated between 24 and 30 ${ }^{\circ} \mathrm{C}$. We incubated the eggs in a 50:50 mix of perlite and vermiculite, with water gradually added until moist enough that a thumb indent held its shape but water was not visible. After 66 days of incubation, all eggs successfully hatched within a 24-h period (Figs. 6-8). At hatching, eggs averaged 19.8 $\mathrm{mm}$ in length (range 18.2-21.0 mm). One hatchling had a severe skull deformation and no eyes; the other five hatchlings appeared perfectly healthy (mean SVL $=36.8 \mathrm{~mm}$, range $36.3-37.3 \mathrm{~mm}$; mean mass $=1.2 \mathrm{~g}$, range $1.14-1.25 \mathrm{~g}$ ).

\section{Literature Cited}

Bartlett, R.D. and P.P. Bartlett. 1999. A Field Guide to Florida Reptiles and Amphibians. Gulf Publishing Co., Houston, Texas.

Camposano, B.J. 2011. Morphological species verification and geographic distribution of Anolis (Sauria: Polychrotidae) in Florida. Unpublished M.S. Thesis, University of Florida, Gainesville.

Crutchfield, T.E. and K.M. Enge. 2008. Geographic distribution: Basiliscus vittatus (Brown Basilisk). Herpetological Review 39: 482.

Engeman, R., E. Jacobson, M.L. Avery, and W.E. Meshaka Jr. 2011. The aggressive invasion of exotic reptiles in Florida with a focus on prominent species: A review. Current Zoology 57: 599-612.

Greene, D.U., B. Hille, S. Sprunt, J.G. Duquesnel, and K.L. Krysko. 2012. First report of a Brown Basilisk (Basiliscus vittatus) from the Florida Keys. Reptiles \& Amphibians 19: 265-266.

King, F.W. and T. Krakauer. 1966. The exotic herpetofauna of southeast Florida. Quarterly Journal of the Florida Academy of Sciences 29: 144-154.

Kolbe, J.J., R.E. Glor, L.R. Schettino, A.C. Lara, A. Larson, and J.B. Losos. 2007. Multiple sources, admixture, and genetic variation in introduced Anolis lizard populations. Conservation Biology 21: 1612-1625.

Krysko, K.L., J.C. Seitz, J.H. Townsend, and K.M. Enge. 2006. The introduced Brown Basilisk (Basiliscus vittatus) in Florida. Iguana 13: 24-30.

Krysko, K.L., K.M. Enge, and P.E. Moler. 2011. Atlas of Amphibians and Reptiles in Florida. Final Report, Project Agreement 08013. Florida Fish and Wildlife Conservation Commission, Tallahassee.

Meshaka, W.E., Jr. 2011. A runaway train in the making: The exotic amphibians, reptiles, turtles, and crocodilians of Florida. Monograph 1. Herpetological Conservation \& Biology 6: 1-101. <http://herpconbio.org/Volume_6/ Monographs/Meshaka_2011.pdfs.

Meshaka, W.E., Jr., B.P. Butterfield, and J.B. Hauge. 2004. The Exotic Amphibians and Reptiles of Florida. Krieger Publishing Co., Malabar, Florida.

Powell, R., R. Conant, and J.T. Collins. 2016. Peterson Field Guide to Reptiles and Amphibians of Eastern and Central North America. 4th ed. Houghton Mifflin Harcourt Publishing Co., Boston, Massachusetts.

Rand, P.L., G.E. Williams, and K.M. Enge. 2008. Geographic distribution: Basiliscus vittatus (Brown Basilisk). Herpetological Review 39: 366.

Savage, J.M. 2002. The Amphibians and Reptiles of Costa Rica: A Herpetofauna between Two Continents, Between Two Seas. University of Chicago Press, Chicago, Illinois.

Snyder, R.C. 1949. Bipedal locomotion of the lizard Basiliscus basiliscus. Copeia 1949: 129-137.

Stroud, J.T. 2014. An introduction to the lizards of Fairchild Tropical Botanical Gardens. The Tropical Garden 69(1): 28-29.

Wilson, L.D. and L. Porras. 1983. The ecological impact of man on the south Florida herpetofauna. University of Kansas Museum of Natural History, Special Publication (9): vi +89 pp. 